\title{
Transactions
}

\section{Terpyridine-fused polyaromatic hydrocarbons generated via cyclodehydrogenation and used as ligands in Ru(II) complexes $\uparrow$}

\author{
Angelika Graczyk, Frances A. Murphy, Deanne Nolan, Vanesa Fernández-Moreira, Natasha J. Lundin, \\ Christopher M. Fitchett and Sylvia M. Draper*
}

Received 7th March 2012, Accepted 1st May 2012

DOI: $10.1039 / \mathrm{c} 2 \mathrm{dt30548h}$

A series of novel fused $4^{\prime}$-substituted $2,2^{\prime}: 6^{\prime}, 2^{\prime \prime}$-terpyridine ligands and their ruthenium(II) complexes were prepared. The unusual $4^{\prime}$-substituents comprised 2,3,4,5-pentaphenylbenzene and its tert-butyl derivative (1 and $\mathbf{2}$ ) and the products from oxidative cyclodehydrogenation, i.e. polyaromatic fragments consisting of ten or thirteen fused benzene rings ( $\mathbf{3}$ and $\mathbf{4}$ ). The syntheses of all the ligands are discussed in terms of the demands and limitations of the Scholl reaction. The optical properties of the ligands, along with the single-crystal X-ray structures of $\mathbf{1}$ and $\mathbf{2}$, are presented. The latter show that the pentaphenylbenzene and terpyridine appendages of $\mathbf{1}$ and $\mathbf{2}$ are perpendicular in the solid state. Despite the inclusion of the large organic chromophore the absorption and emission properties of the $\mathrm{Ru}$ (II) bis-terpy complexes (of ligands $\mathbf{1}, \mathbf{2}$ and $\mathbf{3}$ ) were found to be comparable to those of $\left[\mathrm{Ru}(\mathrm{terpy})_{2}\right]^{2+}$. They are non-emissive at room temperature but emit at $77 \mathrm{~K}$ with excited state lifetimes of 11-12 $\mu$ s.

\section{Introduction}

The extensive exploration of Ru(II) complexes of terpyridinebased (terpy) ligands has been driven by the desirable set of photophysical properties they present and the fact that they offer a non-chiral coordination environment about an octahedral metal centre. ${ }^{1}$ The slight distortion of the octahedral Ru(II) environment induced by terpy coordination reduces the ligand field compared to analogous bipyridyl ligands and renders rapid nonradiative deactivation thermally accessible (via non-emissive ${ }^{3} \mathrm{MC}$ (metal-centred) states). As a result, triplet excited state lifetimes at ambient temperature are generally short, e.g. that of the parent complex $\left[\mathrm{Ru}(\text { terpy })_{2}\right]^{2+}$ is just $0.25 \mathrm{~ns}$ at room temperature. $^{2,3}$ Longer excited state lifetimes are desirable for most optoelectronic applications and a number of different approaches can be used to modify terpy ligands and to extend the lifetimes of their $\mathrm{Ru}$ (II) complexes, e.g. substitution with an electron withdrawing-donating group or the attachment of another organic chromophore. ${ }^{1,4,5}$ In order to achieve an elongation of the excited state lifetime, an appended chromophore needs to have a non-emissive excited state that is similar in energy to the ${ }^{3}$ MLCT (metal-to-ligand charge transfer) state. ${ }^{1}$

School of Chemistry, Trinity College Dublin, Dublin 2, Ireland.

E-mail: smdraper@tcd.ie; Fax: +3531671 2826; Tel: +3531 8962026 $\dagger$ Electronic supplementary information (ESI) available: The crystallographic data and refinement details for compounds $\mathbf{1}$ and 2. ORTEP diagrams of 1 and 2. ${ }^{1} \mathrm{H}$ NMR spectra for novel compounds 3, 4, 6 and 8. CCDC reference numbers 843688 and 843689 . For ESI and crystallographic data in CIF or other electronic format see DOI: $10.1039 / \mathrm{c} 2 \mathrm{dt} 30548 \mathrm{~h}$

t These authors contributed equally to this work.
The ability of complexes to absorb strongly in the visible and near-IR regions is also key for light-harvesting in solar cell applications. Inducing a bathochromic shift of MLCT absorption bands and increasing molar extinction coefficients by extension of $\pi$-conjugation in the ancillary ligand of $\mathrm{Ru}$ (II) polypyridyl complexes are system optimisations which have shown promising photovoltaic results, e.g. excellent incident photon-to-current conversion efficiencies (IPCE). ${ }^{6,7}$

All-benzenoid polyaromatic hydrocarbons (PAHs) are planar, aromatic platforms consisting of a number of fused benzene rings. They display a strong propensity towards $\pi-\pi$ induced aggregation and interesting electronic properties due to their high degree of electron delocalization. ${ }^{8}$ Typically, PAHs are allcarbon sheets, with limited possibilities for the coordination of transition metal centres. As a consequence, our interest was drawn to the easily derivatised hexa-peri-hexabenzocoronene (HBC) subunit, containing thirteen fused aromatic rings. Recently, organometallic complexes of HBC have been generated via $\pi$-coordination of a $\left\{\mathrm{Rh}\left(\mathrm{P}^{\mathrm{i}} \mathrm{Bu}_{3}\right)_{2}\right\}^{+}$fragment, bound $\eta^{6}$ to an outer aromatic ring, ${ }^{9}$ and $\sigma$-coordination of a $\mathrm{Pt}(\mathrm{II})$ acetylide to two aromatic HBC platforms. ${ }^{10}$ The preparation of allcarbon HBCs which bear substituent tridentate ethynyl-terpy ligands has been achieved ${ }^{11}$ and incorporating bidentate nitrogen-based binding sites into PAHs is a recent, though synthetically challenging, advance in the generation of new luminescent materials. $^{12,13}$

In this new work, we hoped to combine the photophysical properties of the $\left[\mathrm{Ru}(\text { terpy })_{2}\right]^{2+}$ fragment with that of a PAH. The resultant bichromophoric ligand would electronically connect the $\pi$-conjugated platform to the terpyridine ligand, providing a concomitant red-shift of MLCT absorption band and an increased molar extinction coefficient. Such a system would 


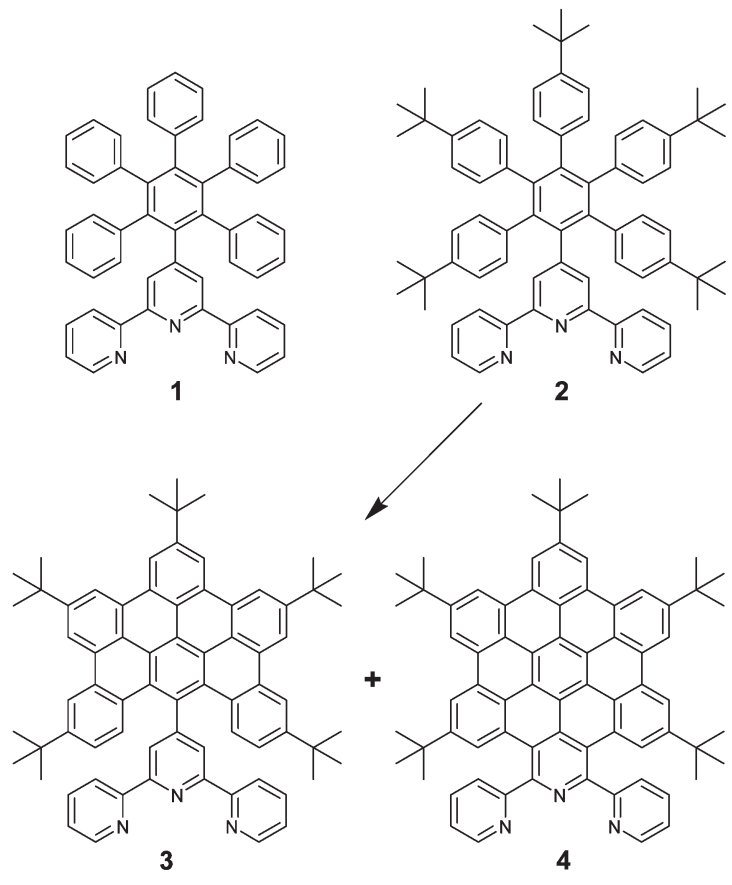

Fig. 1 Terpyridine ligands $\mathbf{1 - 4}$.

extend current synthetic routes and avoid the use of the acetylenic spacer unit, previously used to augment solar-to-electrical energy conversion efficiency. ${ }^{6}$

In this way two essentially isoenergetic triplet excited states would be provided: a ${ }^{3} \mathrm{MLCT}\left(\left[\operatorname{Ru}(\text { terpy })_{2}\right]^{2+}, \lambda \sim 629 \mathrm{~nm}\right)^{14,15}$ and a HBC-localised ${ }^{3} \pi \pi^{*}$ excited state (HBC, $\lambda \sim$ $578 \mathrm{~nm}) .{ }^{10,16,17}$ Excitation into one of these might then give rise to efficient energy equilibration between the two complementary energy levels and substantially prolong the excited state lifetimes. Terpy units have also been shown to be effective synthetic platforms on which to introduce dithiocarbamates as highly stable and robust anchoring units for attachment to $\mathrm{Au}$ surfaces. ${ }^{18}$ In our Ru(II) complexes, surface self-assembly would be driven by $\pi$-stacking interactions between the HBC-fused aromatic platforms, providing uniform surface coverage. The inherent hydrophobicity of the PAH segment would also decrease the probability of water-induced dye degradation in any $\mathrm{Ru}(\mathrm{II})$-dye thin film. ${ }^{19}$

The precursor ligand $\mathbf{1}$ was not new. A recent publication demonstrated the vapochromic behaviour of a platinum(II) complex containing 1 (Fig. 1) and its potential as a colorimetric sensor. ${ }^{20}$ Using a similar procedure we synthesised $\mathbf{1}$, as well as its tert-butyl analogue, 2 (Fig. 1). 2 was subjected to oxidative cyclodehydrogenation to produce two unique ligands, $\mathbf{3}$ and $\mathbf{4}$ (Fig. 1), which contain planar aromatic platforms of ten and thirteen fused benzene rings, respectively. $\mathrm{C}-\mathrm{C}$ bond formation at all the possible cyclisation sites in $\mathbf{2}$ would have produced a system composed of 17 fused aromatic rings. Such an outcome was sterically disfavoured and probably undesirable, given that the resulting extensive increase in electron delocalization would have lowered the energy of the lowest-lying triplet excited state to an extent that the lifetime would be expected to shorten significantly (energy gap law). ${ }^{1}$ In any event, the Ru(II) complexes of ligands 1-3 were key targets for optical investigation as parent complexes, prior to any subsequent piperazinyl dithiocarbamate functionalisation of the unsubstituted terpyridine ligand.

\section{Results and discussion}

\section{Synthesis}

The terpyridine motif was introduced into pentaphenylbenzenes 1 and 2 through the versatile intermediate $4^{\prime}$-[\{(trifluoromethyl)sulfonyl $\}$ oxy $]-2,2^{\prime}: 6^{\prime}, 2^{\prime \prime}$-terpyridine. ${ }^{21}$ This was reacted with either phenylacetylene or 4-tert-butyl-phenylacetylene in order to produce the appropriate acetylene precursor; 4 '-(phenylethynyl)-2,2' $: 6^{\prime}, 2^{\prime \prime}$-terpyridine ${ }^{22}$ or $4^{\prime}$-(4-tert-butyl-phenylethynyl)-2,2':6',2"-terpyridine (5, Scheme 1), respectively. Novel 5 was characterized by NMR spectroscopy and ESI-MS. $4^{\prime}$-(phenylethynyl)-2,2': $6^{\prime}, 2^{\prime \prime}$-terpyridine was then reacted with cyclopentadienone derivatives tetraphenylcyclopentadienone and 2,3,4,5-tetra-(4-tert-butylphenyl)cyclopentadien-1-one, ${ }^{12}$ respectively, producing 1 -(2,2' $: 6^{\prime}, 2^{\prime \prime}$-terpyrid-4'-yl)-2,3,4,5,6-pentaphenylbenzene (1) and 1-(2,2': $6^{\prime}, 2^{\prime \prime}$-terpyrid-4'-yl)-2,3,4,5,6penta(4-tert-butylphenyl) benzene (2). Typical Diels-Alder cycloaddition procedures were employed (heating the reagents at $280^{\circ} \mathrm{C}$ in benzophenone under an argon atmosphere for $7.5 \mathrm{~h}$ ).

Various reaction conditions and oxidants were used to attempt the oxidative cyclodehydrogenation of $\mathbf{1}$ and $\mathbf{2}\left(\mathrm{AlCl}_{3}{ }^{23}\right.$ $\mathrm{MoCl}_{5}{ }^{24}$ and $\mathrm{FeCl}_{3}{ }^{8}$ ). No products could be isolated from the cyclisation of $\mathbf{1}$, which suggests the formation of multiple $\mathrm{C}-\mathrm{C}$ bonds and consequently highly insoluble products. With this in mind, the reaction was repeated, modifying the ligand design, to incorporate solubilising tert-butyl groups on the periphery. Cyclodehydrogenation of 2 using $\mathrm{FeCl}_{3}$ yielded two products after column chromatography, which proved to be partially cyclised 3 as the major product (32\%) and an intriguing nitrogen-substituted hexa-peri-hexabenzocoronene derivative 4 (5\%). $\mathbf{3}$ and $\mathbf{4}$ were fully characterized by NMR spectroscopy and mass spectrometry. Although unusual, in both $\mathbf{3}$ and $\mathbf{4}$ there remain several incomplete $\mathrm{C}-\mathrm{C}$ bond closures, between the generated $\mathrm{PAH}$ and the terpyridine moiety. Two of these (to the terminal pyridyl rings) are clearly sterically hindered but the fact that $\mathbf{3}$ is the major product would suggest that the formation of the $\mathrm{C}-\mathrm{C}$ bonds to the central pyridine ring is also disfavoured. The latter can be rationalized by giving some consideration to the mechanism of the cyclodehydrogenation reaction.

The most plausible mechanism for the Scholl reaction (the condensation of aromatics under the influence of a Lewis acid) is reported to involve the generation of radical cations which can take part in a series of cascade reactions. ${ }^{25,26}$ Under highly acidic conditions, the initial reaction relies on protonation of the non-planar polyphenylene to give a radical cation that takes part in electrophilic attack and undergoes deprotonation and subsequent oxidation. In the known systems where nitrogen atoms are present in the hexaphenylbenzene precursor, cyclodehydrogenation is initiated at pyrimidyl rings. ${ }^{13,27}$ These basic nitrogen atoms are protonated preferentially, giving an arenium cation which is positively charged at positions ortho and para to the site of protonation. For pyrimidyl-substituted hexaphenylbenzenes such as the N-HSB and N-1/2HSB precursor, (a) in Scheme 2, this results in the formation of an ortho $\mathrm{C}-\mathrm{C}$ bond on 


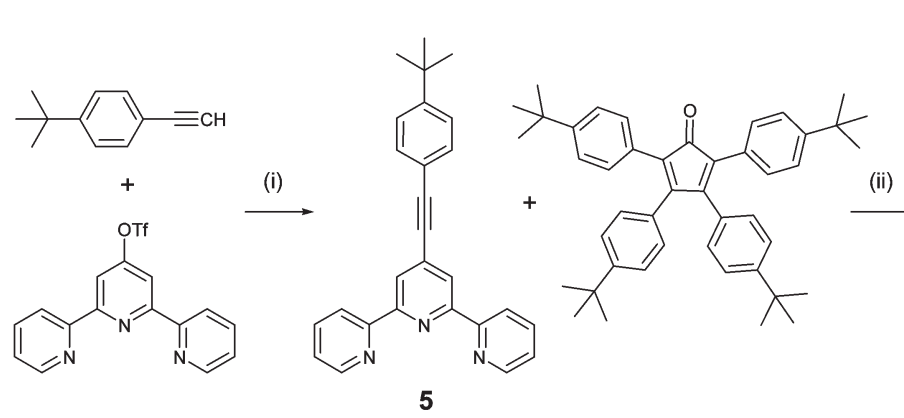

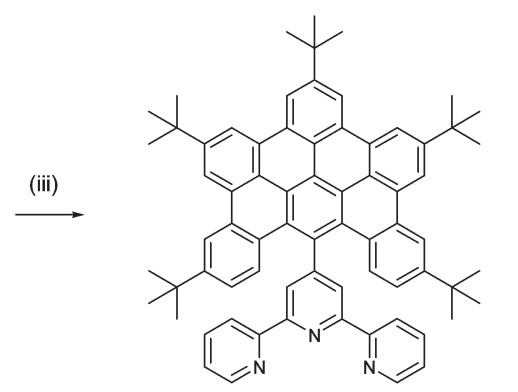

3

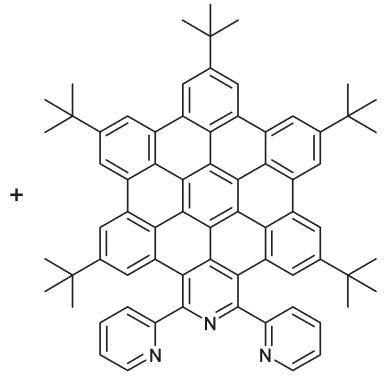

4<smiles>CC(C)(C)c1ccc(-c2c(-c3ccc(C(C)(C)C)cc3)c(-c3ccc(C(C)(C)C)cc3)c(-c3ccccn3)c(-c3ccc(C(C)(C)C)cc3)c2-c2ccc(-c3ccccn3)nc2)cc1</smiles>

Scheme 1 The synthesis of ligands 2, 3 and $\mathbf{4}$ and terpyridine-acetylene precursor 5. (i) $\mathrm{Pd}_{(}\left(\mathrm{PPh}_{3}\right)_{2} \mathrm{Cl}_{2}, \mathrm{CuI}$, triethylamine, toluene $70{ }^{\circ} \mathrm{C}, 4.5$ h, $75 \%$; (ii) benzophenone $280{ }^{\circ} \mathrm{C}, 7 \mathrm{~h}, 52 \%$; (iii) $\mathrm{CH}_{2} \mathrm{Cl}_{2}, \mathrm{FeCl}_{3}\left(20\right.$ eq. in $\mathrm{CH}_{3} \mathrm{NO}_{2}$ ), 24 h, 3: $34 \%, 4: 5 \%$.<smiles></smiles>

(a)

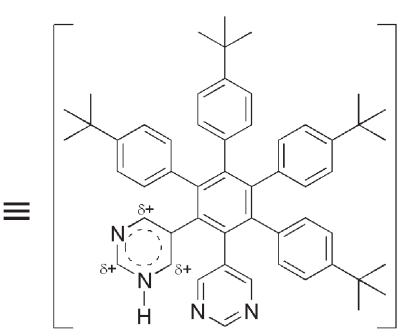

(b)<smiles>CC(C)(C)C1=CC2C3N=CNC=C3c3c(-c4ccc(C(C)(C)C)cc4)c(-c4ccc(C(C)(C)C)cc4)c(-c4ccc(C(C)(C)C)cc4)c(-c4ccc(C(C)(C)C)cc4)c3C2C=C1</smiles>

(c)

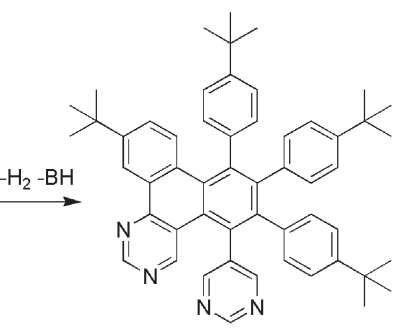

(d)<smiles>C#CC(C)(C)c1ccc(-c2c(-c3ccc(C(C)(C)C)cc3)c(-c3ccc(C(C)(C)C)cc3)c(-c3ccc(C(C)(C)C)cc3)c(-c3ccc(C(C)(C)C)cc3)c2-c2ccc(C(C)(C)C)cc2)cc1</smiles>

2

Scheme 2 Radical cation mechanism for the intermolecular Scholl reaction in formation of N-HSB derivatives (top) and the carbocation intermediate formed by protonation of $\mathbf{2}$ (bottom), where $\mathrm{C}-\mathrm{C}$ bond formation at sites adjacent to the pyridyl ring is disfavoured.

an adjacent ring and $\mathrm{C}-\mathrm{C}$ bond formation at the pyrimidyl end of the molecule.

In the case of terpyridine 2, preferential protonation of the central pyridyl ring generates a cationic charge at the ortho and para positions, but $\mathrm{C}-\mathrm{C}$ bond formation requires activation at the carbon in the meta position (Scheme 2). The same is also true of protonation at the peripheral pyridyl rings. Cyclodehydrogenation in this case proceeds in a more efficient manner between the five posterior tert-butylphenyl rings, leaving the terpy unit less connected to the platform and $\mathbf{3}$ as the major product.

\section{Crystal structures}

Crystals suitable for single-crystal X-ray diffraction were obtained for $\mathbf{1}$ and $\mathbf{2}$ by slow evaporation of $\mathrm{CHCl}_{3}$ and $\mathrm{CH}_{2} \mathrm{Cl}_{2}$ 


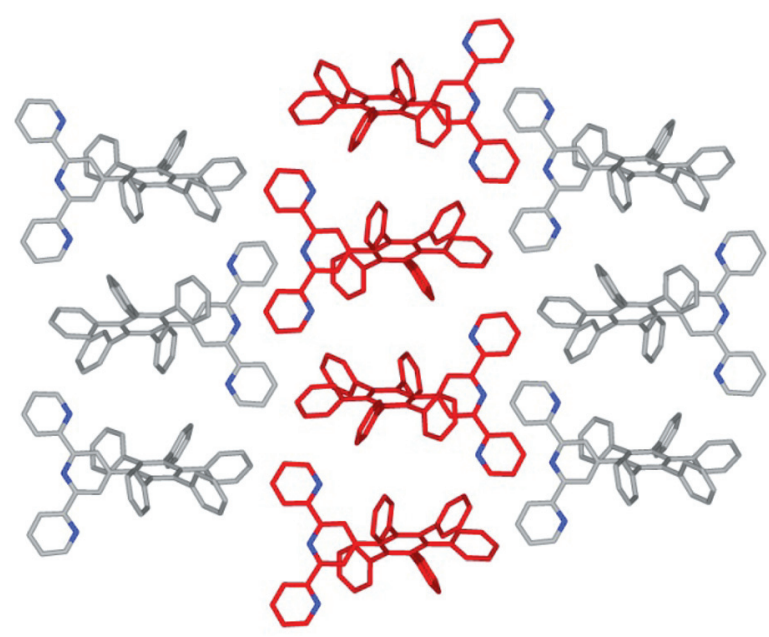

Fig. 2 Perspective view of crystal packing in $\mathbf{1}$ (solvent molecules omitted for clarity).

solutions, respectively.§ In the structure of $\mathbf{1}$ the asymmetric unit contains one molecule of the ligand and three molecules of $\mathrm{CHCl}_{3}$. The terpy end of ligand $\mathbf{1}$ is bent by $56.8^{\circ}$ with respect to the central benzene ring and the tilt angles for the external phenyl rings vary from $65^{\circ}$ to $70^{\circ}$. Fig. 2 shows the organisation between molecules of $\mathbf{1}$, which are not involved in any form of $\pi$-stacking. The perspective view shows that the molecules form head-to-tail columns.

In the crystal structure of $\mathbf{2}$, the asymmetric unit contains one molecule of 2 and two molecules of $\mathrm{CH}_{2} \mathrm{Cl}_{2}$. The terpyridine unit is almost perpendicular to the central benzene ring $\left(86.9^{\circ}\right)$, while the five tert-butylphenyl rings are typically propeller-like and twisted between $64^{\circ}$ and $82^{\circ}$ with respect to the central

§ Crystallographic data. A suitable crystal of each compound $\mathbf{1}$ and $\mathbf{2}$ was selected and mounted using inert oil on a $0.30 \mathrm{~mm}$ quartz fibre tip and immediately placed on the goniometer head in a $123 \mathrm{~K} \mathrm{~N}_{2}$ gas stream. The data was collected on a Bruker Smart Apex CCD Diffractometer using graphite-monochromated $\operatorname{MoK}_{\alpha}(\lambda=0.71073 \AA)$ and Bruker Smart Version 5.625 software run in multirun mode. 2400 image frames of $0.3^{\circ}$ per frame were recorded. Data integration and reduction were carried out using Bruker Saint+ Version 6.45 software $^{31}$ and corrected for absorption and polarization effects using SADABS Version 2.10 software. ${ }^{32}$ Space group determination, structure solution and refinement were obtained using Shelxtl ver. 6.14 software. ${ }^{33}$ The structures both converged to a reasonable $R$ factor. All the non-hydrogen atoms were refined anisotropically, and the hydrogen atoms were fixed from the residual electron density using appropriate HFIX commands. Intermolecular interactions were computed using the PLATON program. Further details and ORTEP diagrams are provided in the Supporting Information. $\dagger$ CCDC-843688 (1) and CCDC-843689 (2) contain the supplementary crystallographic data for this paper. $\dagger$

Crystal data for $\mathbf{1 . 3 C} \mathbf{H C l}_{3} . \mathrm{C}_{54} \mathrm{H}_{38} \mathrm{Cl}_{9} \mathrm{~N}_{3}, M_{\mathrm{r}}=1047.92$, monoclinic, space group $=P 2(1) / n, a=11.5279(5) \AA, b=17.3151(8) \AA, c=$ 25.3288(12) $\AA, \beta=95.0820^{\circ}, U=5035.9(4) \AA^{3}, T=153(2) \mathrm{K}, Z=4$, 44768 reflections measured, 10440 unique $\left(R_{\text {int }}=0.0285\right)$ which were used in all calculations. The final $R_{1}$ (all data) was 0.0595 and $\mathrm{w} R_{2}$ (all data) was 0.1707 .

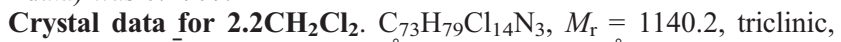
space group $=P \overline{1}, a=12.2579(7) \AA, b=16.5216(9) \AA, c=18.2312(10)$ $\AA, \alpha=66.3110^{\circ}, \beta=70.3760^{\circ}, \gamma=76.7660^{\circ}, U=3165.7(3) \AA^{3}, T=$ $153(2) \mathrm{K}, Z=2,31713$ reflections measured, 12437 unique $\left(R_{\text {int }}=\right.$ $0.0297)$ which were used in all calculations. The final $R_{1}$ (all data) was 0.0801 and $\mathrm{w} R_{2}$ (all data) was 0.2070 .

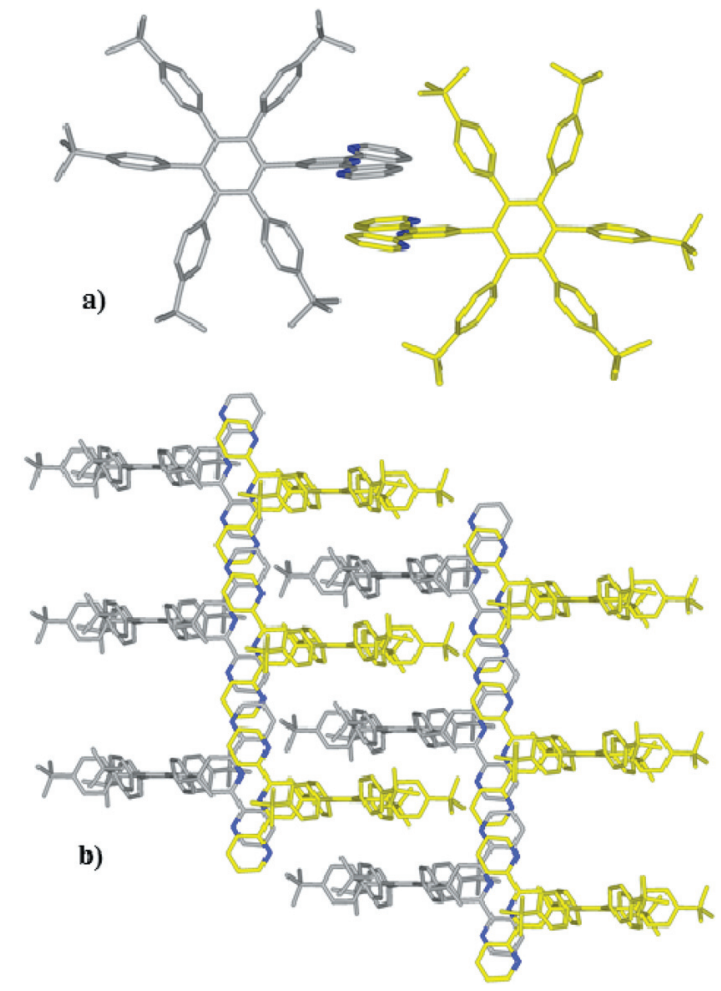

Fig. 3 (a) The $\pi-\pi$ stacking interaction between two molecules of 2 . (b) The packing arrangement between molecules of $\mathbf{2}$ as viewed along the $y$ axis (solvent molecules omitted for clarity).

benzene ring. Ligand 2 shows intermolecular $\pi$-stacking at the terpy end of the molecule with a distance of $3.74 \AA$ between the molecules (Fig. 3a). Fig. 3b shows the extended packing arrangement between molecules of $\mathbf{2}$ along the $y$ axis. The molecules are shown in yellow and grey layers which associate through this dimeric $\pi-\pi$ interaction.

\section{Ru(II) complexes}

$\mathrm{Ru}(\mathrm{II})$ complexes of the terpyridine ligands were synthesised; homoleptic complex $\left[\mathrm{Ru}(\mathbf{1})_{2}\right]\left(\mathrm{PF}_{6}\right)_{2}(\mathbf{6})$ was produced by reacting ligand 1 directly with $\mathrm{RuCl}_{3}$ under reducing conditions while the heteroleptic complexes $[\mathrm{Ru}($ terpy $)(2)]\left(\mathrm{PF}_{6}\right)_{2}(7)$ and $[\mathrm{Ru}($ terpy $)(3)]\left(\mathrm{PF}_{6}\right)_{2}(\mathbf{8})$ were prepared by reacting the respective ligands with the precursor $\left[\mathrm{Ru}\left(\right.\right.$ terpy) $\left.\mathrm{Cl}_{3}\right]{ }^{28}$ Unfortunately, it was not possible to produce ligand $\mathbf{4}$ in sufficient amounts to facilitate synthesis of its corresponding $\mathrm{Ru}(\mathrm{II})$ complex, $[\mathrm{Ru}($ terpy $)(4)]\left(\mathrm{PF}_{6}\right)_{2}$. Heteroleptic complexes 7 and 8 were prepared so that the influence of the large aromatic ligands on the excited state of the $\left[R u(t e r p y)_{2}\right]^{2+}$ could be determined. All the compounds were characterized by NMR spectroscopy and gave satisfactory ESI-MS results.

\section{Absorption spectroscopy}

The UV-vis absorption spectra for ligands 1-4 in acetonitrile are presented in Fig. 4. 1 and $\mathbf{2}$ show very similar absorption profiles, arising from $\pi-\pi^{*}$ and $\mathrm{n}-\pi^{*}$ transitions, with absorption 


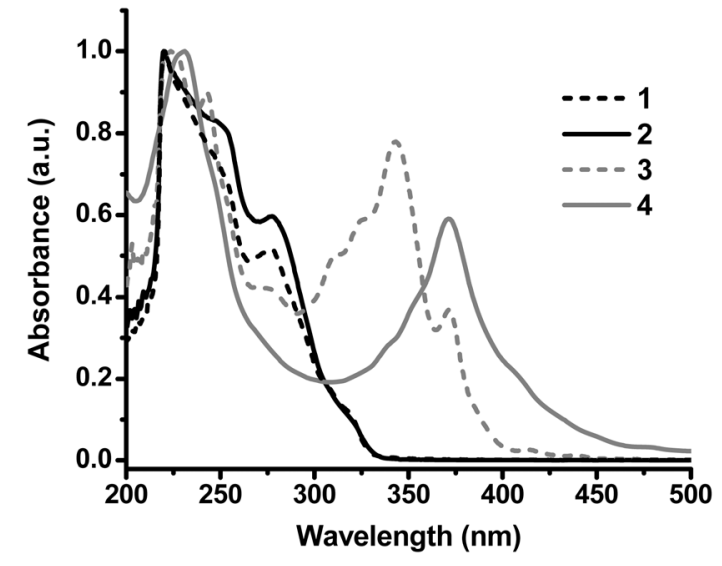

Fig. 4 Normalized absorption spectra for ligands $\mathbf{1 - 4}$, in $\mathrm{CH}_{3} \mathrm{CN}$ at room temperature $\left(\sim 10^{-5} \mathrm{M}\right)$.

Table 1 Absorption maxima for ligands 1-4 and Ru(II) complexes 6-8 in $\mathrm{CH}_{3} \mathrm{CN}$ at room temperature $\left(\sim 10^{-5} \mathrm{M}\right)$

\begin{tabular}{|c|c|c|}
\hline Compound & \multicolumn{2}{|l|}{$\lambda_{\max }^{\mathrm{abs}}(\mathrm{nm})$} \\
\hline 1 & \multicolumn{2}{|c|}{$221,254,279$} \\
\hline 2 & \multicolumn{2}{|c|}{$220,248,279$} \\
\hline 3 & \multirow{2}{*}{\multicolumn{2}{|c|}{$\begin{array}{c}224,244,280 s h, 323,343,372,439 \\
231,335 s h, 350 s h, 371,405 s h\end{array}$}} \\
\hline 4 & & \\
\hline 6 & 278,310 & 486 \\
\hline 7 & 271,308 & 484 \\
\hline 8 & $271,309,338$ & 488 \\
\hline$\left[\mathrm{Ru}(\text { terpy })_{2}\right]^{2+29}$ & 270,307 & 475 \\
\hline
\end{tabular}

maxima around $\lambda 250$ and $279 \mathrm{~nm}$. In the spectrum of $\mathbf{3}$, a number of additional lower energy transitions involving the aromatic platform appear (Table 1). These are in the same region as the $\pi-\pi^{*}$ transitions observed in HBC derivatives, although the shape of the absorption profile differs due to the smaller aromatic platform in this case. For $\mathbf{4}$, absorptions related to the $\pi-\pi^{*}$ transitions of the planar aromatic platform are shifted to longer wavelengths (around $\lambda 371 \mathrm{~nm}$ ), as is typical for HBC-type compounds and are broadened and less structured due to enhanced aggregation effects. ${ }^{10,11}$

$\mathrm{Ru}(\mathrm{II})$ complexes 6, 7 and $\mathbf{8}$ show a number of ligand-centred $\pi-\pi^{*}$ bands at higher energy wavelengths and a lower energy MLCT $\left(\mathrm{d}-\pi^{*}\right)$ transition at around $\lambda 485 \mathrm{~nm}$ (Fig. 5). ${ }^{30}$ The ligand-centred (LC) bands show a red shift of 25-30 nm on coordination; for example the band observed at $\lambda 280 \mathrm{~nm}$ in the free ligands appears at approximately $\lambda 310 \mathrm{~nm}$ in all the complexes. The spectrum of $\mathbf{8}$ has a larger number of LC bands compared with the other complexes (Fig. 5) due to the extended $\pi$ conjugation of its heteroleptic ligand. The relative energies of the MLCT transitions are similarly affected by the ligands and are lowest for $8(\lambda 488 \mathrm{~nm})$ and highest for $7(\lambda 484 \mathrm{~nm})$, where the electron donating effect of the five tert-butyl substituents exerts an influence. On comparison with $\left[\mathrm{Ru}(\text { terpy })_{2}\right]^{2+}$, all three complexes show red-shifted MLCT-based absorptions, however the effect of the differing 4'-substituents is surprisingly small. (Unsubstituted $\left[\mathrm{Ru}(\text { terpy })_{2}\right]^{2+}$ has an MLCT transition at $\lambda$ $475 \mathrm{~nm}^{29}$ whereas $\left[\mathrm{Ru}(\text { phterpy })_{2}\right]^{2+}$ complex absorbs at $\lambda$ $\left.487 \mathrm{~nm}^{5}\right)$.

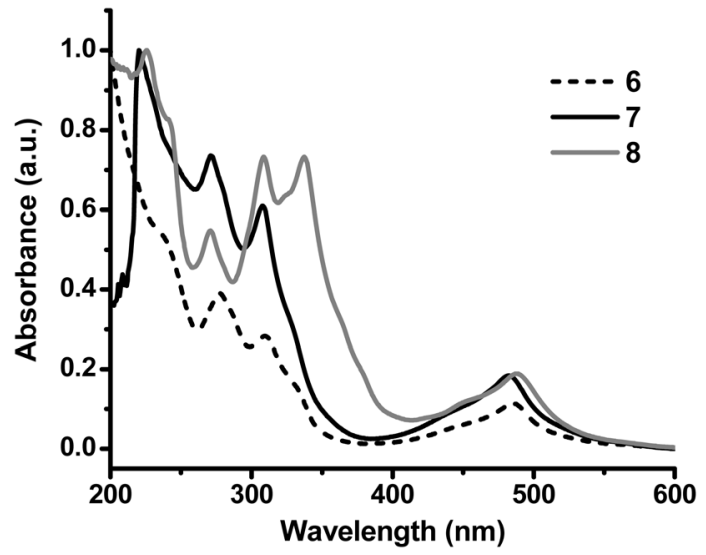

Fig. 5 Normalized absorption data of Ru(II) complexes 6, 7 and 8 in $\mathrm{CH}_{3} \mathrm{CN}$ at room temperature $\left(\sim 10^{-5} \mathrm{M}\right)$.

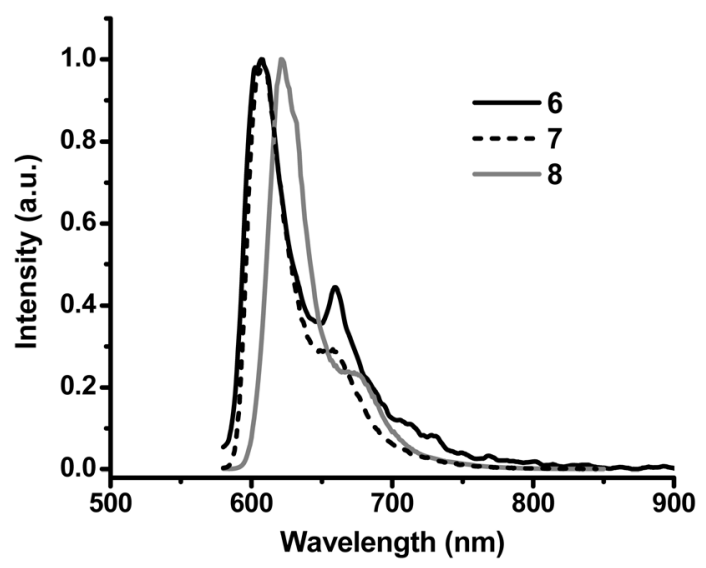

Fig. 6 Normalised emission of Ru(II) complexes 6, 7 and 8 at $77 \mathrm{~K}$ in $4: 1$ ethanol-methanol $\left(\sim 10^{-5} \mathrm{M}\right)$.

\section{Emission spectroscopy}

All three complexes are non-emissive at room temperature but luminesce at $77 \mathrm{~K}$ (Fig. 6). Such behaviour is similar to that of the parent complex $\left[\mathrm{Ru}(\text { terpy })_{2}\right]^{2+}$ and several other $\mathrm{Ru}(\mathrm{II})$ complexes containing terpyridine-based ligands. ${ }^{30}$ The effect is due to the coupling of the emitting ${ }^{3}$ MLCT state with a nonemissive metal-centred triplet state $\left({ }^{3} \mathrm{MC}\right)$, which provides an efficient non-radiative deactivation pathway at ambient temperature. At lower temperature the ${ }^{3} \mathrm{MC}$ is no longer thermally accessible and ${ }^{3}$ MLCT-based emission is observed. The emission profiles of 6-8 exhibit significant vibrational fine structure and are typical of ${ }^{3} \mathrm{MLCT}$ emission at low temperature. 8 emits at a maximum of $\lambda 620 \mathrm{~nm}$ at $77 \mathrm{~K}$, representing a red shift of $12 \mathrm{~nm}$ compared with $7(\lambda 607 \mathrm{~nm})$, as a consequence of its increased electron delocalization and the lowering of the LUMO. Extended aromatic frameworks are known to lower the energy of the LUMO, resulting in emission at longer wavelengths, e.g. [Ru$\left.(\text { bpy })_{2}(\mathrm{NHSB})\right]^{2+}$ and $\left[\mathrm{Ru}(\mathrm{bpy})_{2}(1 / 2-\mathrm{NHSB})\right]^{2+}$ emit in the nearIR region $\left(\lambda 880 \mathrm{~nm}^{12}\right.$ and $\left.\lambda 868 \mathrm{~nm}^{13}\right)$ whereas emission from $\left[\mathrm{Ru}(\mathrm{bpy})_{3}\right]^{2+}$ occurs at $\lambda 626 \mathrm{~nm}$. The relatively small stabilization of the emission energy of $\mathbf{8} v s .7$ suggests that communication between the terpyridine and polyaromatic regions of the ligand is limited, in agreement with the UV-Vis data. 
Table 2 Emission data for $\mathrm{Ru}(\mathrm{II})$ complexes $\mathbf{6}, 7$ and 8 (77 K, $4: 1$ ethanol-methanol) $\left(\sim 10^{-5} \mathrm{M}\right)$

\begin{tabular}{lll}
\hline Complex & Emission $\left(\lambda_{\max } / \mathrm{nm}\right)$ & $\tau(\mu \mathrm{s})$ \\
\hline $\mathbf{6}$ & 606,660 & $11( \pm 0.02)$ \\
$\mathbf{7}$ & 607,660 & $11( \pm 0.02)$ \\
$\mathbf{8}$ & 620,671 & $12( \pm 0.01)$ \\
\hline
\end{tabular}

For the tris-bpy type $\left[\mathrm{Ru}(\mathrm{bpy})_{2}(\mathrm{NHSB})\right]^{2+}$ complexes, the fused NHSB ligand is directly attached to the metal centre whilst in $\mathbf{8}$, the chelating terpy unit does not form part of the fused aromatic structure. In fact, given the crystal structure of $\mathbf{2}$ and the additional unfavourable interactions between the hydrogen atoms ortho to the inter-annular bond and tert-butyl substituent groups in $\mathbf{3}$, it is highly likely that the $\left[\mathrm{Ru}(\text { terpy })_{2}\right]^{2+}$ chromophore and the fused aromatic sheet have limited interaction both in the ground state and excited state due to a forced perpendicular arrangement.

The excited-state lifetimes of complexes $\mathbf{6 , 7} 7$ and $\mathbf{8}$ were measured at low temperature in $4: 1$ ethanol-methanol solutions using a single photon photomultiplier detection system. The excitation source used was a picosecond NanoLED laser fixed at $\lambda 460 \mathrm{~nm}$; emission was detected at $\lambda_{\max }^{\mathrm{em}}=610 \mathrm{~nm}$ for 6 and 7 and at $\lambda 620 \mathrm{~nm}$ for $\mathbf{8}$. Complex $\mathbf{8}$ has a slightly longer-lived excited state lifetime than the other two complexes, at $12 \mu \mathrm{s}$ (Table 2).

The excited state lifetimes of $\mathbf{6}, \mathbf{7}$ and $\mathbf{8}$ are very similar to those of $\left[\operatorname{Ru}(\text { terpy })_{2}\right]^{2+}(\tau=10.6 \mu \mathrm{s})$ and $\left[\operatorname{Ru}(\text { phterpy })_{2}\right]^{2+}(\tau=$ $11.9 \mu \mathrm{s}) .^{5}$ This is indicative of the relatively limited influence exerted by the polyphenyl and PAH groups in complexes 6-8 on the $\left[\mathrm{Ru}(\text { terpy })_{2}\right]^{2+}$ excited state. Work is currently underway toward modifying the synthesis of $\mathbf{4}$ and the preparation of $[\mathrm{Ru}($ terpy $)(4)]\left(\mathrm{PF}_{6}\right)_{2}$. This ligand would not be expected to demonstrate the same steric constraints as a portion of the terpyridyl fragment is directly incorporated into the PAH backbone. Therefore, a more ready lowering of the ${ }^{3}$ MLCT excited state would be anticipated in addition to more efficient equilibration between the ${ }^{3} \mathrm{MLCT}$ and ${ }^{3} \pi \pi^{*}$ energy levels. These results emphasize the electronic and steric factors that need to be taken into consideration in designing ligands that successfully tune the excited state of $\left[\operatorname{Ru}(\text { terpy })_{2}\right]^{2+}$ complexes. Optimisation of the synthesis of $\mathbf{4}$ and its complex, in combination with further modification to attach a piperazinyl dithiocarbamate moiety to the unsubstituted terpyridine ligand, should produce systems with MLCT absorption bands sufficiently red-shifted to optimise absorption of sunlight photons throughout the visible light spectrum.

\section{Conclusion}

Four 4'-substituted terpyridine ligands have been prepared, two of which contain large polyaromatic hydrocarbon fragments. Of these, $\mathbf{3}$ and $\mathbf{4}$, support fused systems comprising ten and thirteen rings and are the newest members of an exclusive family of ligand-functionalised PAHs. The dominance of $\mathbf{3}$ as the major product on the oxidative cyclodehydrogenation of polyphenylene 2 led us to rationalize the effect of pyridyl rings on the Scholl reaction. Ligands 1-3 were used to prepare a series of $\mathrm{Ru}(\mathrm{II})$ complexes which were found to have absorption and emission characteristics similar to those of the parent complex [Ru(terpy $\left.)_{2}\right]\left(\mathrm{PF}_{6}\right)_{2}$. This implies minimal interaction between the $\left[\mathrm{Ru}(\text { terpy })_{2}\right]^{2+}$ unit and the polylphenyl/PAH appendages in these complexes, and is thought to be a consequence of the nonplanar arrangement of the substituent and terpy end groups. In order to optimise electronic communication, the work points to the need to generate chromophores that adopt a co-planar arrangement and gives further impetus to the formation of $\mathbf{4}$ and derivatives like it.

\section{Experimental}

\section{General methods}

Tetraphenylcyclopentadienone (Aldrich) and $\mathrm{RuCl}_{3}$ (Johnson Matthey) were used as received. 4'-[\{(trifluoromethyl)sulfonyl $\}$ -

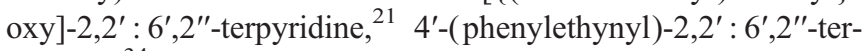
pyridine, ${ }^{34}$ 2,3,4,5-tetra-(4-tert-butylphenyl)cyclopentadien-1one ${ }^{12}$ and $\left[\mathrm{Ru}(\text { terpy }) \mathrm{Cl}_{3}\right]^{28}$ were prepared according to literature procedures. 1 was prepared by a different method to that previously published $\mathrm{d}^{20}$ thus the procedure is presented below. All reactions were carried out under inert conditions. Nuclear magnetic resonance spectra were recorded in deuterated acetonitrile or chloroform with a Bruker Avance DPX-400 MHz spectrometer at the following frequencies: $400.13 \mathrm{MHz}$ for ${ }^{1} \mathrm{H}$ and 100.6 MHz for ${ }^{13} \mathrm{C}$. The signals for ${ }^{1} \mathrm{H}$ and ${ }^{13} \mathrm{C}$ spectra were referenced to TMS at $\delta \quad 0.0 \mathrm{ppm}$, coupling constants were recorded in hertz $(\mathrm{Hz})$ to two decimal places. ${ }^{13} \mathrm{C}$ signals were assigned with the aid of DEPT 145 and DEPT 90 experiments. 2-D correlation spectra were employed to assign the ${ }^{1} \mathrm{H}$ and ${ }^{13} \mathrm{C}$ peaks. Homonuclear correlation spectroscopy was performed using TOCSY or ${ }^{1} \mathrm{H}-{ }^{1} \mathrm{H}$ COSY experiments, heteronuclear correlation spectroscopy was performed using HSQC, $\mathrm{HMQC}$ or HMBC (long-range) experiments. Electrospray mass spectra were recorded on a Micromass-LCT spectrometer and accurate mass spectra were referenced against leucine enkephalin $\left([\mathrm{M}+\mathrm{H}]^{+} \mathrm{m} / \mathrm{z} 556.2771 \mathrm{~g} \mathrm{~mol}^{-1}\right)$ and reported to within $5 \mathrm{ppm}$. The MALDI-TOF mass spectrum of $\mathbf{4}$ was recorded on a Waters MALDI-QTOF premier spectrometer using a DCTB matrix (trans-2-[3-(4-tert-butylphenyl)-2-methyl-2-propenylidene]malononitrile) and accurate mass spectra were referenced against $\left[\mathrm{Glu}^{1}\right]$-Fibrinopeptide B $\left([\mathrm{M}+\mathrm{H}]^{+} \mathrm{m} / z 1570.6768 \mathrm{~g} \mathrm{~mol}^{-1}\right)$ and reported to within $5 \mathrm{ppm}$. Elemental analyses were performed in the Microanalytical Laboratory, University College Dublin. Compounds were thoroughly dried in vacuo. However, despite multiple attempts, it was not possible to obtain consistent, accurate elemental analysis results for $\mathbf{4}$. This finding is not uncommon where large thermally robust polyaromatic compounds are involved and can be attributed to incomplete combustion of the carbon framework. In the alternative the ${ }^{1} \mathrm{H}$ NMR spectrum and the experimental (+)-MALDI-TOF spectrum and $(\mathrm{M})^{+}$simulated isotopic distribution pattern are provided for compound $\mathbf{4}$ in the ESI (Fig. S3 and S4 $\dagger$ ).

\section{Photophysical measurements}

All photophysical studies were carried out with solutions contained within $1 \times 1 \mathrm{~cm}^{2}$ quartz cells in HPLC grade solvents and 
were degassed using argon bubbling. UV-visible absorption spectra were recorded on a Shimadzu UV-2450 spectrophotometer and the data was analysed using UVProbe software. Fluorescence spectra were recorded on a Varian Cary Eclipse luminescence spectrometer. The excited-state lifetimes of complexes $\mathbf{6}, \mathbf{7}$ and $\mathbf{8}$ were measured at low temperature in $4: 1$ ethanol-methanol solutions using a single photon photomultiplier detection system. The excitation source used was a picosecond NanoLED laser fixed at $460 \mathrm{~nm}$; emission was detected at $\lambda_{\max }^{\mathrm{em}}=610 \mathrm{~nm}$ for complexes 6 and 7 and at $620 \mathrm{~nm}$ for complex 8 . The resulting data were collected and lifetimes were determined from the observed decays with the F900 software (Edinburgh Instruments). The decay was fitted using a first order exponential decay model (Fit $=A+B \mathrm{e}^{\left(-\tau / \tau_{1}\right)}$ where $A=$ background constant, $B=$ the pre-exponential factor and $\tau_{1}$ is the lifetime of the excited state) and the goodness of fit was evaluated for each result by considering the $\chi^{2}$ values and inspecting the residual plots.

1-(2,2' : 6',2'-Terpyrid-4'-yl)-2,3,4,5,6-pentaphenylbenzene (1). $4^{\prime}$-(phenylethynyl)-2,2' $: 6^{\prime}, 2^{\prime \prime}$-terpyridine $(0.3 \mathrm{~g}, 0.9 \mathrm{mmol})$, tetraphenylcyclopentadienone $(0.33 \mathrm{~g}, 0.9 \mathrm{mmol})$ and benzophenone $(3.5 \mathrm{~g})$ were heated at $280{ }^{\circ} \mathrm{C}$ for $7.5 \mathrm{~h}$ under argon. Carbon dioxide was evolved and the colour changed from purple to brown. After cooling the product was purified by column chromatography $\left(\mathrm{SiO}_{2}, \mathrm{CHCl}_{3}-\mathrm{MeOH}, 30: 1\right.$ then the polarity was increased by elution with $\mathrm{CHCl}_{3}-\mathrm{MeOH}-\mathrm{NH}_{3 \mathrm{aq}}, 10: 1: 1$ ) giving 1 as a white powder $(0.3 \mathrm{~g}, 48 \%)$. Anal. Calcd for $\mathrm{C}_{51} \mathrm{H}_{35} \mathrm{~N}_{3} \cdot 1 / 2\left(\mathrm{CH}_{3} \mathrm{OH}\right)$ : C, 87.63; H, 5.28; N, 5.95. Found: C, 87.78; H, 5.30; N, 5.86. ESI-MS (MeOH) $m / z 690.2918[\mathrm{M}+$ $\mathrm{H}]^{+}$(calcd for $\mathrm{C}_{51} \mathrm{H}_{36} \mathrm{~N}_{3}$ : 690.2909). $\delta_{\mathrm{H}}\left(400 \mathrm{MHz} ; \mathrm{CDCl}_{3}\right.$; $\left.\mathrm{Me}_{4} \mathrm{Si}\right) 8.61(\mathrm{~d}, 2 \mathrm{H}, J=4 \mathrm{~Hz}), 8.36(\mathrm{~d}, 2 \mathrm{H}, J=8 \mathrm{~Hz}), 8.05$ (s, 2H), 7.35 (ddd, $2 \mathrm{H}, J=7.6$ and $1.5 \mathrm{~Hz}$ ), 7.24 (ddd, $2 \mathrm{H}, J=4.5$ and $1 \mathrm{~Hz}), 7.02(\mathrm{~d}, 4 \mathrm{H}, J=7 \mathrm{~Hz}), 6.86(\mathrm{~m}, 20 \mathrm{H}), 6.79(\mathrm{t}, 2 \mathrm{H}$, $J=7.5 \mathrm{~Hz}) \mathrm{ppm} . \delta_{\mathrm{C}}\left(101 \mathrm{MHz} ; \mathrm{CDCl}_{3} ; \mathrm{Me}_{4} \mathrm{Si}\right) 155.6(2 \mathrm{C})$, 153.2 (2C), 150.6 (2C), 148.5 (2C), 140.5, 140.0 (2C), 139.9, 139.8 (2C), 139.4 (2C), 139.3 (2C), 137.7, 136.0 (2C), 130.8, 130.7 (4C), 126.3, 126.1, 125.1 (2C), 124.8, 123.4 (2C), 122.8 (2C), 120.4 (2C) ppm.

4'-(4-tert-Butyl-phenylethynyl)-2,2' : 6',2"-terpyridine (5). Copper iodide $(25 \mathrm{mg}, 0.125 \mathrm{mmol}$ ) was added to a degassed solution of 4-tert-butyl-phenylacetylene $(0.389 \mathrm{~g}, 2.46 \mathrm{mmol}), 4$ '-[\{(trifluoromethyl)sulfonyl $\}$ oxy $]-2,2^{\prime}: 6^{\prime}, 2^{\prime \prime}$-terpyridine $(0.62 \mathrm{~g}, 1.63 \mathrm{mmol})$ and $\left[\mathrm{Pd}\left(\mathrm{PPh}_{3}\right)_{2} \mathrm{Cl}_{2}\right](89 \mathrm{mg}, 0.127 \mathrm{mmol})$ in toluene-triethylamine $(1: 1,25 \mathrm{ml})$. The reaction mixture was stirred at $70{ }^{\circ} \mathrm{C}$ for $3 \mathrm{~h}$. Solvents were removed under reduced pressure and then the product was purified by column chromatography $\left(\mathrm{SiO}_{2}, \mathrm{DCM}-\right.$ acetone $49: 1)$ giving 5 as a white powder $(0.49 \mathrm{~g}, 77 \%)$. Anal. Calcd for $\mathrm{C}_{27} \mathrm{H}_{23} \mathrm{~N}_{3} \cdot 1 / 3 \mathrm{H}_{2} \mathrm{O}$ : C, 82.00; H, 6.03; N, 10.62. Found: C, $81.82 ; \mathrm{H}, 5.94 ; \mathrm{N}, 10.54$. ESI-MS $\left(\mathrm{CH}_{3} \mathrm{OH}\right) \mathrm{m} / z=390.1976$ $[\mathrm{M}+\mathrm{H}]^{+}$, (calcd for $\left.\mathrm{C}_{27} \mathrm{H}_{24} \mathrm{~N}_{3}: 390.1970\right) . \delta_{\mathrm{H}}\left(400 \mathrm{MHz} ; \mathrm{CDCl}_{3}\right.$; $\left.\mathrm{Me}_{4} \mathrm{Si}\right) 8.75(\mathrm{~d}, 2 \mathrm{H}, J=5.52 \mathrm{~Hz}), 8.65(\mathrm{~d}, 2 \mathrm{H}, J=8 \mathrm{~Hz}), 8.59(\mathrm{~s}$, 2H), 7.89 (ddd, $2 \mathrm{H}, J=8 \mathrm{~Hz}, 2 \mathrm{~Hz}), 7.55$ (m, 2H, $J=8.5 \mathrm{~Hz}$ ), 7.44 (m, 2H, $J=8.5 \mathrm{~Hz}$ ), 7.37 (ddd, $2 \mathrm{H}, J=4.5 \mathrm{~Hz}, 1 \mathrm{~Hz}), 1.36$ (s, 9H) ppm. $\delta_{\mathrm{C}}\left(101 \mathrm{MHz} ; \mathrm{CDCl}_{3} ; \mathrm{Me}_{4} \mathrm{Si}\right) 155.3$ (2C), 155.0 (2C), 154.7, 151.9 (2C), 148.7, 136.5 (2C), 133.3 (2C), 131.3, 125.1 (4C), $123.6(2 \mathrm{C}), 122.4(2 \mathrm{C}), 120.8(2 \mathrm{C}), 119.0,116.2$ (4C), 34.5, 30.1 (3C) ppm.
1-(2,2' : 6',2'-Terpyrid-4'-yl)-2,3,4,5,6-penta-(4-tert-butylphenyl)benzene (2). 5 ( $0.127 \mathrm{~g}, 0.33 \mathrm{mmol}), 2,3,4,5$-tetra-(4-tert-butylphenyl)cyclopentadienone $(0.2 \mathrm{~g}, 0.33 \mathrm{mmol})$ and benzophenone $(1.5 \mathrm{~g})$ were heated at $280{ }^{\circ} \mathrm{C}$ for $7.5 \mathrm{~h}$ under argon. Carbon dioxide was evolved and colour changed from purple to brown. After cooling the product was purified by column chromatography $\left(\mathrm{SiO}_{2}, \mathrm{CHCl}_{3}-\mathrm{MeOH}, 30: 1\right)$ to give 2 as a white powder $(0.17 \mathrm{~g}, 56 \%)$. Anal. Calcd for $\mathrm{C}_{71} \mathrm{H}_{75} \mathrm{~N}_{3}$ : C, 87.88; H, 7.79; N, 4.33. Found: C, 87.68; H, 7.71; N, 4.24. ESI-MS $\left(\mathrm{CH}_{3} \mathrm{OH}\right) \mathrm{m} / \mathrm{z}=970.6018[\mathrm{M}+\mathrm{H}]^{+}$(calcd for $\mathrm{C}_{71} \mathrm{H}_{76} \mathrm{~N}_{3}$ : 970.6039). $\delta_{\mathrm{H}}\left(400 \mathrm{MHz} ; \mathrm{CDCl}_{3} ; \mathrm{Me}_{4} \mathrm{Si}\right) 8.60(\mathrm{~d}, 2 \mathrm{H}, J=$ $4 \mathrm{~Hz}$ ), 8.11 (d, $2 \mathrm{H}, J=8 \mathrm{~Hz}), 7.83$ (s, 2H), 7.67 (ddd, $2 \mathrm{H}, J=8$, $1.5 \mathrm{~Hz}), 7.20(\mathrm{ddd}, 2 \mathrm{H}, J=4.5 \mathrm{~Hz}), 6.84-6.72(\mathrm{~m}, 20 \mathrm{H}), 1.13$ $(\mathrm{s}, 9 \mathrm{H}), 1.12(\mathrm{~s}, 18 \mathrm{H}), 0.95(\mathrm{~s}, 18 \mathrm{H}) \mathrm{ppm} . \delta_{\mathrm{C}}\left(101 \mathrm{MHz} ; \mathrm{CDCl}_{3}\right.$; $\left.\mathrm{Me}_{4} \mathrm{Si}\right) 155.1$ (2C), 153.5 (2C), 150.8, 149.0 (2C), 147.4, 147.0, $140.9,140.2,139.3,136.7$ (2C), 135.7, 131.1, 131.0, 124.3 (2C), 123.0, 122.6, $122.4(2 \mathrm{C}), 121.0(2 \mathrm{C}), 33.5(5 \mathrm{C}), 30.7$ (9C), 30.4 (6C) ppm.

4'-3,6,9,12,15-Penta-tert-butyldibenzo[fg,ij]phenanthro[9,10,1, 2,3-pqrst]pentaphen-18-yl)-2,2' : 6',2'"-terpyridine (3) and (4). A solution of iron(III) chloride $(0.5 \mathrm{~g}, 3 \mathrm{mmol})$ in nitromethane $(4.5 \mathrm{~mL})$ was added drop-wise to a stirring solution of $2(0.15 \mathrm{~g}$, $0.154 \mathrm{mmol})$ in dichloromethane $(35 \mathrm{~mL})$. Argon was bubbled though the mixture for $2 \mathrm{~h}$, then the mixture was stirred under an argon atmosphere for a further $48 \mathrm{~h}$. The reaction was quenched with methanol $(50 \mathrm{~mL})$, washed with water and extracted into dichloromethane, dried $\mathrm{MgSO}_{4}$ and the solvent removed under reduced pressure. The crude product was purified by column chromatography $\left(\mathrm{SiO}_{2}\right)$. Terpyridine 4 was eluted first $(8 \mathrm{mg}$, $5 \%$, using a solvent mixture of $\mathrm{CHCl}_{3}-\mathrm{MeOH}(30: 1$, and increasing the polarity to $4: 1$ ). Partially fused 3 was eluted by increasing the solvent polarity to $\mathrm{CHCl}_{3}-\mathrm{MeOH}(1: 1)$ and finally to $\mathrm{CHCl}_{3}-\mathrm{MeOH}-\mathrm{NH}_{3}(\mathrm{aq})(1: 1: 0.5)$ giving 3 (50 mg, $32 \%$ ).

4: MALDI-TOF MS $\left(\mathrm{CH}_{3} \mathrm{CN}\right) \mathrm{m} / z 957.5010[\mathrm{M}]^{+}$(calcd for $\mathrm{C}_{71} \mathrm{H}_{63} \mathrm{~N}_{3}$ : 957.5022). $\delta_{\mathrm{H}}\left(101 \mathrm{MHz} ; \mathrm{CDCl}_{3} ; \mathrm{Me}_{4} \mathrm{Si}\right) 9.33$ $(\mathrm{s}, 2 \mathrm{H}), 9.32\left(\mathrm{~d}, 2 \mathrm{H},{ }^{4} \mathrm{~J}=1.5 \mathrm{~Hz}\right), 9.26\left(\mathrm{~d}, 2 \mathrm{H},{ }^{4} \mathrm{~J}=1.5 \mathrm{~Hz}\right)$, $9.15\left(\mathrm{~d}, 2 \mathrm{H},{ }^{4} \mathrm{~J}=1.5 \mathrm{~Hz}\right), 8.78\left(\mathrm{~d}, 2 \mathrm{H},{ }^{3} \mathrm{~J}=4.3 \mathrm{~Hz}\right), 8.45(\mathrm{~d}, 2 \mathrm{H}$, $\left.{ }^{4} \mathrm{~J}=1.5 \mathrm{~Hz}\right), 8.22\left(\mathrm{~d}, 2 \mathrm{H},{ }^{4} \mathrm{~J}=7.8 \mathrm{~Hz}\right), 7.98\left(\mathrm{dd}, 2 \mathrm{H},{ }^{3} \mathrm{~J}=\right.$ $\left.7.7 \mathrm{~Hz},{ }^{4} \mathrm{~J}=1.8 \mathrm{~Hz}\right), 7.44\left(\mathrm{ddd}, 2 \mathrm{H},{ }^{3} \mathrm{~J}=7.7,5.0 \mathrm{~Hz},{ }^{4} \mathrm{~J}=\right.$ $1.1 \mathrm{~Hz}), 1.83(\mathrm{~s}, 9 \mathrm{H}), 1.81(\mathrm{~s}, 18 \mathrm{H}), 1.35(\mathrm{~s}, 18 \mathrm{H}) \mathrm{ppm} . \delta_{\mathrm{C}}$ (101 MHz; $\left.\mathrm{CDCl}_{3} ; \mathrm{Me}_{4} \mathrm{Si}\right) 150.0$ (2C), 149.7 (4C), 149.2 (4C), 134.1 (2C), 131.0 (4C), 130.5 (4C), 130.4 (4C), 130.3 (2C), 126.7 (6C), 125.2 (2C), 124.2 (2C), 123.6 (2C), $121.6(2 \mathrm{C})$, 120.7 (2C), 119.3 (5C), 119.2 (4C), 35.9 (2C), 35.8 (4C), 35.2 (4C), 32.0 (9C), 31.5 (6C) ppm.

3: Anal. Calcd for $\mathrm{C}_{71} \mathrm{H}_{67} \mathrm{~N}_{3} \cdot \mathrm{CH}_{3} \mathrm{OH}$ : C, 87.32; $\mathrm{H}, 6.82 ; \mathrm{N}$, 4.24. Found: C, 87.03; H, 6.61; N, 4.37. ESI-MS (MeOH) $\mathrm{m} / \mathrm{z}$ $962.5399[\mathrm{M}+\mathrm{H}]^{+}$(calcd for $\mathrm{C}_{71} \mathrm{H}_{68} \mathrm{~N}_{3}$ : 962.5413). $\delta_{\mathrm{H}}$ (400 MHz; $\left.\mathrm{CDCl}_{3} ; \mathrm{Me}_{4} \mathrm{Si}\right) 9.16(\mathrm{~s}, 2 \mathrm{H}), 9.11$ (s, 2H), 8.98 (s, 2H), 8.69 (s, 4H), 8.67 (d, 2H, $J=7.5 \mathrm{~Hz}), 8.62$ (d, 2H, $J=$ $4 \mathrm{~Hz}$ ), 7.91 (ddd, $2 \mathrm{H}, J=7.5,1.5 \mathrm{~Hz}), 7.51$ (d, 2H, $J=9 \mathrm{~Hz}$ ), 7.33 (ddd, 2H, $J=6,1 \mathrm{~Hz}$ ), 6.98 (d, 2H, $J=8.5 \mathrm{~Hz}$ ), 1.82 (s, $9 \mathrm{H}), 1.78(\mathrm{~s}, 18 \mathrm{H}), 1.38(\mathrm{~s}, 18 \mathrm{H}) \mathrm{ppm} . \delta_{\mathrm{C}}\left(101 \mathrm{MHz} ; \mathrm{CDCl}_{3}\right.$; $\left.\mathrm{Me}_{4} \mathrm{Si}\right) 156.2$ (2C), 155.8 (2C), 155.2 (2C), 148.9 (2C), 148.7, 136.2 (2C), 132.0, 131.5 (2C), 130.9, 129.8, 129.3, $127.3(2 \mathrm{C})$, $125.5,124.5,123.1$ (2C), 122.7, 122.5, 122.3, 121.7 (2C), 120.8 
(2C), 118.8 (2C), 118.5 (2C), 118.4 (2C), 117.5 (2C), 35.3, 35.2 (2C), 34.3 (2C), $31.6(3 \mathrm{C}), 31.5$ (6C), 30.7 (6C) ppm.

$\left[\mathbf{R u}(\mathbf{1})_{2}\right]\left(\mathbf{P F}_{\mathbf{6}}\right)_{\mathbf{2}} \mathbf{( 6 )} \mathbf{1}(50 \mathrm{mg}, 0.73 \mathrm{mmol})$ was dissolved in a $1: 1$ mixture of ethanol-chloroform $(5 \mathrm{~mL})$. The solution was degassed by bubbling a stream of argon through the flask. After $30 \mathrm{~min} \mathrm{RuCl}_{3}(7.5 \mathrm{mg}, 0.36 \mathrm{mmol})$ was added and then the reaction mixture was flushed with argon for $20 \mathrm{~min} .4$ drops of $\mathrm{N}$-ethylmorpholine were added and then the reaction mixture was refluxed for $6 \mathrm{~h}$. After cooling, the mixture was filtered and the chloroform was evaporated under reduced pressure. To the ethanol solution a saturated solution of $\mathrm{KPF}_{6}$ was added and a deep orange precipitate was formed. The crude product was purified by column chromatography $\left(\mathrm{Al}_{2} \mathrm{O}_{3}, \mathrm{CH}_{3} \mathrm{CN}-\right.$ sat. aq. $\left.\mathrm{KNO}_{3}-\mathrm{H}_{2} \mathrm{O}, 10: 0.5: 1.5\right)$ giving 6 (19 mg, 30\%.). Anal. Calcd for $\mathrm{C}_{102} \mathrm{H}_{70} \mathrm{~N}_{6} \mathrm{P}_{2} \mathrm{~F}_{12} \mathrm{Ru}$ : C, 69.19; H, 3.98; N, 4.75. Found: C, 68.98; $\mathrm{H}, 4.04 ; \mathrm{N}, 4.86$. ESI-MS $\left(\mathrm{CH}_{3} \mathrm{CN}\right) \mathrm{m} / \mathrm{z} 740.2365$ $\left[\mathrm{M}-2 \mathrm{PF}_{6}\right]^{2+}$ (calcd. 740.2352). $\delta_{\mathrm{H}}\left(400 \mathrm{MHz} ; \mathrm{CD}_{3} \mathrm{CN} ; \mathrm{Me}_{4} \mathrm{Si}\right.$ ) 8.14 (s, 4H), 8.06 (d, 4H, $J=8 \mathrm{~Hz}), 7.84(\mathrm{dd}, 4 \mathrm{H}, J=7.5 \mathrm{~Hz})$, $7.25(\mathrm{~d}, 8 \mathrm{H}, J=7.5 \mathrm{~Hz}), 7.18(\mathrm{dd}, 4 \mathrm{H}, J=6.5 \mathrm{~Hz}), 7.09-6.96$ $(\mathrm{m}, 38 \mathrm{H}), 6.90$ (t, 4H, $J=7 \mathrm{~Hz}), 6.60(\mathrm{~d}, 4 \mathrm{H}, J=5.5 \mathrm{~Hz}) \mathrm{ppm}$. $\delta_{\mathrm{C}}\left(101 \mathrm{MHz} ; \mathrm{CD}_{3} \mathrm{CN} ; \mathrm{Me}_{4} \mathrm{Si}\right) 158.1,157.1,156.2,152.6$, 150.5 (2C), 149.2, 141.9, 140.3, 139.6, 139.5, 139.3, 139.2, 137.6 (2C), 136.7, 131.3 (4C), 130.8 (4C), 130.7 (2C), 127.0 (2C), 126.7 (4C), 126.5 (4C), 126.4 (2C), 125.9 (2C), 125.5 (2C), 125.4 (1C), 125.3 (2C), 123.5 (2C) ppm.

$\left[\mathbf{R u}\left(\right.\right.$ terpy)(2)](PF $\mathbf{~}_{\mathbf{2}} \mathbf{2}$ (7). $\mathbf{2}$ (20 $\left.\mathrm{mg}, 0.021 \mathrm{mmol}\right)$ was dissolved in ethylene glycol $(4 \mathrm{~mL})$ and the mixture was degassed by bubbling a stream of argon through the flask for $30 \mathrm{~min}$. Ru(terpy) $\mathrm{Cl}_{3}(9.1 \mathrm{mg}, 0.021 \mathrm{mmol})$ was added and the reaction mixture was heated at $90{ }^{\circ} \mathrm{C}$ for $6 \mathrm{~h}$. After cooling, a saturated solution of $\mathrm{KPF}_{6}$ was added to obtain a deep orange precipitate. The crude product was purified by preparative TLC $\left(\mathrm{SiO}_{2}\right.$, $\left.\mathrm{CH}_{3} \mathrm{CN}-\mathrm{KNO}_{3}-\mathrm{H}_{2} \mathrm{O}, 10: 0.5: 1.5\right)$ giving 7 (9.7 mg, $\left.30 \%\right)$. Anal. Calcd for $\mathrm{C}_{86} \mathrm{H}_{86} \mathrm{~N}_{6} \mathrm{P}_{2} \mathrm{~F}_{12} \mathrm{Ru}$ : C, 64.77; H, 5.44; N, 5.27. Found: C, 64.49; H, 5.28; N, 5.49. ESI-MS $\left(\mathrm{CH}_{3} \mathrm{CN}\right) \mathrm{m} / \mathrm{z}$ $652.2985\left[\mathrm{M}-2 \mathrm{PF}_{6}\right]^{2+}($ calcd 652.2979$) . \delta_{\mathrm{H}}(400 \mathrm{MHz}$; $\left.\mathrm{CD}_{3} \mathrm{CN} ; \mathrm{Me}_{4} \mathrm{Si}\right) 8.74$ (d, $\left.2 \mathrm{H}, J=8 \mathrm{~Hz}\right), 8.50$ (d, $\left.2 \mathrm{H}, J=8 \mathrm{~Hz}\right)$, 8.39 (t, $1 \mathrm{H}, J=8 \mathrm{~Hz}), 7.96(\mathrm{dd}, 2 \mathrm{H}, J=8 \mathrm{~Hz}), 7.92(\mathrm{~s}, 2 \mathrm{H})$, $7.84(\mathrm{~d}, 2 \mathrm{H}, J=7.5 \mathrm{~Hz}), 7.77$ (dd, $2 \mathrm{H}, J=7.5 \mathrm{~Hz}), 7.34$ (dd, $2 \mathrm{H}, J=6.5 \mathrm{~Hz}), 7.19(\mathrm{dd}, 2 \mathrm{H}), 7.16-7.08(\mathrm{~m}, 8 \mathrm{H}), 7.06(\mathrm{~d}, 2 \mathrm{H})$, $7.04(\mathrm{~d}, 2 \mathrm{H}), 7.02(\mathrm{~d}, 2 \mathrm{H}, J=8 \mathrm{~Hz}), 6.96(\mathrm{~m}, 6 \mathrm{H}, J=8 \mathrm{~Hz})$, $6.84(\mathrm{~d}, 4 \mathrm{H}, J=8 \mathrm{~Hz}), 1.16(\mathrm{~s}, 27 \mathrm{H}), 0.81(\mathrm{~s}, 18 \mathrm{H}) \mathrm{ppm} . \delta_{\mathrm{C}}$ (101 MHz; $\left.\mathrm{CD}_{3} \mathrm{CN} ; \mathrm{Me}_{4} \mathrm{Si}\right)$ 158.1, 157.3, 155.0, 152.7, 152.3 (2C), 150.9 (2C), 149.3, 149.0, 148.6, 148.3, 143.2, 141.1, $140.0,138.0(2 \mathrm{C}), 137.7$ (2C), 136.9, 136.5, 135.6, 135.5 (2C), $131.9,130.8,130.6,129.6,127.5(2 \mathrm{C}), 127.0(2 \mathrm{C}), 128.2$, 126.2, $124.4(2 \mathrm{C}), 123.9$ (2C), 123.7 (2C), 123.5 (2C), 123.3, 33.7 (5C), 30.32 (3C), 30.30 (6C), 30.1 (6C) ppm.

$[\mathbf{R u}($ terpy $)(\mathbf{3})]\left(\mathbf{P F}_{\mathbf{6}}\right)_{2} \mathbf{( 8 )} .3$ (20 mg, $\left.0.021 \mathrm{mmol}\right)$ was dissolved in ethylene glycol $(4 \mathrm{~mL})$ and the mixture was degassed by bubbling a stream of argon through the flask for $30 \mathrm{~min}$. $\mathrm{Ru}$ (terpy) $\mathrm{Cl}_{3}(9.1 \mathrm{mg}, 0.021 \mathrm{mmol})$ was added and the reaction mixture was heated at $90{ }^{\circ} \mathrm{C}$ for $6 \mathrm{~h}$. After cooling, a saturated solution of $\mathrm{KPF}_{6}$ was added to obtain a deep orange precipitate. The crude product was purified by preparative TLC $\left(\mathrm{SiO}_{2}\right.$, $\left.\mathrm{CH}_{3} \mathrm{CN}-\mathrm{KNO}_{3}-\mathrm{H}_{2} \mathrm{O}, 10: 0.5: 1.5\right)$ yielding 8 (9.9 mg, 30\%). Anal. Calcd for $\mathrm{C}_{86} \mathrm{H}_{78} \mathrm{~N}_{6} \mathrm{P}_{2} \mathrm{~F}_{12}$ Ru. $\mathrm{H}_{2} \mathrm{O}$ : C, 64.37; H, 5.03;
N, 5.24. Found: $\mathrm{C}, 64.21 ; \mathrm{H}, 5.31 ; \mathrm{N}, 5.15$. ESI-MS $\left(\mathrm{CH}_{3} \mathrm{CN}\right)$ $m / z 648.775\left[\mathrm{M}-2 \mathrm{PF}_{6}\right]^{2+}($ calcd 648.550$) . \delta_{\mathrm{H}}(400 \mathrm{MHz}$; $\left.\mathrm{CD}_{3} \mathrm{CN} ; \mathrm{Me}_{4} \mathrm{Si}\right) 9.36(\mathrm{~s}, 2 \mathrm{H}), 9.32(\mathrm{~s}, 2 \mathrm{H}), 9.21(\mathrm{~s}, 2 \mathrm{H}), 9.09$ (s, 2H), 8.93 (s, 2H), 8.88 (d, 2H, $J=8 \mathrm{~Hz}), 8.65$ (d, 2H, $J=8$ $\mathrm{Hz}), 8.52$ (t, $1 \mathrm{H}, J=8 \mathrm{~Hz}), 8.19$ (d, 2H, $J=8 \mathrm{~Hz}), 8.11$ (dd, 2H, $J=7.5 \mathrm{~Hz}), 7.85(\mathrm{~m}, 4 \mathrm{H}), 7.78(\mathrm{~d}, 2 \mathrm{H}, J=5.5 \mathrm{~Hz}), 7.51(\mathrm{dd}$, $2 \mathrm{H}, J=6 \mathrm{~Hz}), 7.47(\mathrm{~d}, 2 \mathrm{H}, J=5 \mathrm{~Hz}), 7.27(\mathrm{~d}, 2 \mathrm{H}, J=8.5 \mathrm{~Hz})$, $7.21(\mathrm{dd}, 2 \mathrm{H}, J=6 \mathrm{~Hz}), 1.85(\mathrm{~s}, 9 \mathrm{H}), 1.83(\mathrm{~s}, 18 \mathrm{H}), 1.42(\mathrm{~s}$, $18 \mathrm{H})$ ppm. $\delta_{\mathrm{C}}\left(101 \mathrm{MHz} ; \mathrm{CD}_{3} \mathrm{CN} ; \mathrm{Me}_{4} \mathrm{Si}\right) 158.3,158.1,156.0$, $155.2,152.8,152.5$ (2C), 151.6 (2C), 150.8, 150.6, 150.4, 138.3 (2C), 137.9 (2C), 135.9, 132.7, 132.0 (2C), 130.4, 130.2, 130.0, 129.7, 127.9 (2C), 127.4 (2C), 127.3 (2C), 127.1 (2C), 125.1, 124.6 (2C), $124.1(2 \mathrm{C}), 123.9$ (2C), 122.9, 122.6, 122.0, 121.8, 121.0, 120.2 (2C), 119.8 (2C), 119.7 (2C), 118.7 (2C), 35.6, 35.5 (2C), $34.5(2 \mathrm{C}), 30.98(6 \mathrm{C}), 30.92$ (9C) ppm.

\section{Acknowledgements}

The authors thank Dr John O'Brien, Dr Manuel Reuther and Dr Martin Feeney for technical assistance. The work presented was supported financially by Science Foundation Ireland [SFIPICA-05] (AG, FM, CF), [SFIRFP-09-MTR2366] (DN), a European Union FP6 Marie Curie award [EU-FP6-014472] (VFM) and an Irish Research Council postdoctoral award [IRCSET08] (NL).

\section{References}

1 E. A. Medlycott and G. S. Hanan, Chem. Soc. Rev., 2005, 34, 133-142.

2 J. M. Calvert, J. V. Caspar, R. A. Binstead, T. D. Westmoreland and T. J. Meyer, J. Am. Chem. Soc., 1982, 104, 6620-6627.

3 J. R. Winkler, T. L. Netzel, C. Creutz and N. Sutin, J. Am. Chem. Soc., 1987, 109, 2381-2392.

4 E. A. Medlycott and G. S. Hanan, Coord. Chem. Rev., 2006, 250, $1763-1782$.

5 M. Maestri, N. Armaroli, V. Balzani, E. C. Constable and A. M. W. C. Thompson, Inorg. Chem., 1995, 34, 2759-2767.

6 F. Gao, Y. Wang, D. Shi, J. Zhang, M. Wang, X. Jing, R. HumphryBaker, P. Wang, S. M. Zakeeruddin and M. Grätzel, J. Am. Chem. Soc., 2008, 130, 10720-10728.

7 M. Chandrasekharam, G. Rajkumar, C. Srinivasa Rao, T. Suresh, M. Anil Reddy, P. Yella Reddy, Y. Soujanya, B. Takeru, Y. Jun-Ho, M. K. Nazeeruddin and M. Grätzel, Synth. Met., 2011, 161, 1098-1104.

8 J. Wu, W. Pisula and K. Müllen, Chem. Rev., 2007, 107, 718-747.

9 A. Woolf, A. B. Chaplin, J. E. McGrady, M. A. M. Alibadi, N. Rees, S. Draper, F. Murphy and A. S. Weller, Eur. J. Inorg. Chem., 2011, 2011, 1614-1625.

10 D. Nolan, B. Gil, F. A. Murphy and S. M. Draper, Eur. J. Inorg. Chem., 2011, 2011, 3248-3256.

11 F. A. Murphy and S. M. Draper, J. Org. Chem., 2010, 75, 1862-1870.

12 S. M. Draper, D. J. Gregg and R. Madathil, J. Am. Chem. Soc., 2002, 124, 3486-3487.

13 D. J. Gregg, E. Bothe, P. Hofer, P. Passaniti and S. M. Draper, Inorg. Chem., 2005, 44, 5654-5660.

14 Y.-Q. Fang, N. J. Taylor, G. S. Hanan, F. Loiseau, R. Passalacqua, S. Campagna, H. Nierengarten and A. V. Dorsselaer, J. Am. Chem. Soc., 2002, 124, 7912-7913.

15 S. Campagna, F. Puntoriero, F. Nastasi, G. Bergamini and V. Balzani, Top. Curr. Chem., 2007, 280, 117-214.

16 K. Y. Kim, S. Liu, M. E. Kose and K. S. Schanze, Inorg. Chem., 2006, 45, 2509-2519.

17 B. El Hamaoui, F. Laquai, S. Baluschev, J. Wu and K. Müllen, Synth. Met., 2006, 156, 1182-1186.

18 F. A. Murphy, S. Suarez, E. Figgemeier, E. R. Schofield and S. M. Draper, Chem.-Eur. J., 2009, 15, 5740-5748.

19 K.-J. Jiang, N. Masaki, J.-b. Xia, S. Noda and S. Yanagida, Chem. Commun., 2006, 2460-2462. 
20 P. Du, J. Schneider, W. W. Brennessel and R. Eisenberg, Inorg. Chem., 2008, 47, 69-77.

21 K. T. Potts and D. Konwar, J. Org. Chem., 1991, 56, 4815-4816.

22 S. Ott, M. Borgstroem, M. Kritikos, R. Lomoth, J. Bergquist, B. Aakermark, L. Hammarstroem and L. Sun, Inorg. Chem., 2004, 43, 4683-4692.

23 C. Kubel, K. Eckhardt, V. Enkelmann, G. Wegner and K. Mullen, J. Mater. Chem., 2000, 10, 879-886.

24 B. Kramer, R. Fröhlich and S. R. Waldvogel, Eur. J. Org. Chem., 2003, 3549-3554.

25 P. Rempala, J. Kroulik and B. T. King, J. Am. Chem. Soc., 2004, 126, 15002-15003.

26 P. Rempala, J. Kroulik and B. T. King, J. Org. Chem., 2006, 71, 5067-5081.

27 S. Nagarajan, C. Barthes and A. Gourdon, Tetrahedron, 2009, 65, 3767-3772.
28 A. C. Benniston, G. Chapman, A. Harriman, M. Mehrabi and C. A. Sams, Inorg. Chem., 2004, 43, 4227-4233.

29 E. C. Constable and A. M. W. Cargill Thompson, J. Chem. Soc., Dalton Trans., 1994, 1409-1418.

30 J. P. Sauvage, J. P. Collin, J. C. Chambron, S. Guillerez, C. Coudret, V. Balzani, F. Barigelletti, L. De Cola and L. Flamigni, Chem. Rev., 1994, 94, 993-1019.

31 SAINT+ Software Reference Manual, version 5.625, Bruker AXS Inc., Madison, WI, 2001.

32 G. M. Sheldrick, SADABS. Version 2.10, Bruker AXS Inc., Madison, WI, 2005.

33 G. M. Sheldrick, SHELXTL Version 6.14, An Integrated System for Data Collection, Processing, Structure Solution and Refinement, Bruker AXS Inc., Madison, WI, 2001.

34 K. T. Potts, M. J. Cipullo, P. Ralli and G. Theodoridis, J. Org. Chem., 1982, 47, 3027-3038. 